\title{
Distribution, source apportionment and health risk assessment of organochlorine pesticides in drinking groundwater
}

John A. O. Oyekunle

Obafemi Awolowo University

Abiodun 0. Adegunwa

Osun State University

Odunayo T. Ore ( $\boldsymbol{D}$ oreodunayo@yahoo.com )

Obafemi Awolowo University https://orcid.org/0000-0002-5529-1509

\section{Research}

Keywords: Organochlorine pesticides, ground water, source apportionment, health risk, lle-Ife, Nigeria

Posted Date: February 10th, 2021

DOI: https://doi.org/10.21203/rs.3.rs-152579/v3

License: (c) (i) This work is licensed under a Creative Commons Attribution 4.0 International License.

Read Full License 


\section{Abstract}

Groundwater samples of Ile-Ife, Osun State, Nigeria were investigated for their organochlorine pesticides (OCPs) levels. Probable sources of the OCPs and health risks associated with their consumption along with the water were determined in order to establish the potability of the groundwater samples. Quantitative determination of the OCPs was carried out by Gas Chromatography coupled with Electron Capture Detector (GC-ECD) after liquid-liquid extraction with dichloromethane (DCM). Results indicated that all the analyzed OCPs except p,p'-dichlorodiphenylethane were detected with high concentrations in the groundwater. Heptachlor $(14.60 \pm 3.60 \mu \mathrm{g} \mathrm{L}-1)$ and methoxychlor $(12.60 \pm 2.20 \mu \mathrm{g} \mathrm{L}-1)$ showed dominant concentrations that were higher than $0.02 \mathrm{ng} \mathrm{L-1}$ maximum residue levels (MRLs) recommended by the European Union. Levels of the OCPs in the samples followed the decreasing trend: cyclodienes > diclorophehylethanes > chlorinated cyclohexanes, while the predominant source of the analyzed pesticides could be ascribed to aerial transportation from fresh applications in homes within the community. The carcinogenic health risk assessment also revealed consistent higher values of $\mathrm{HQ}$ and $\mathrm{CR}$ in children as opposed to adults, indicating that children are the more vulnerable population to the analyzed environmental contaminants.

\section{Introduction}

Organochlorine pesticides (OCPs) are a group of chlorinated persistent organic pollutants (POPs) that have found vast applications in chemical industries and agriculture to mitigate, destroy and control pests including weeds and vectors of human and animal diseases that affect production, processing and storage of agricultural produce due to their versatility [1]. The widespread distribution of OCPs in one form or the other through practices in agriculture and public health programs has posed negative impacts on human health through inhalation, ingestion and dermal contact and this has become a key concern over the years $[2,3]$.

Application of pesticides to farm lands is the major way through which pesticides are released into the environment [4]. Though this practice has been banned in most developed countries due to the associated health risks, however, pesticides potent capacity to increase the yield of agricultural produce by inhibiting pest attacks and the fact that they are readily available makes their usage to be advancing in many African countries [3].

Organochlorine pesticides have been listed as priority pollutants due to their hepatotoxic, carcinogenic, and mutagenic effects as they have capacity to accumulate in the tissues of living organisms causing detrimental health effects [5]. Literature reported that there are still some residual concentrations of OCPs in some regions in the developed countries after several years of their applications owing to their persistent and high resistant to degradation. In Nigeria, there have been some levels of researches on the presence of OCPs in sediments, water and vegetables [3, 4, 6-9] 
Basically, human exposure to pesticides can occur through inhalation of air, consumption of agricultural food items and drinking contaminated water. However, major pathway of OCPs to human and natural ecosystem is mostly through hydrological systems. Water is one of the primary ways through which OCPs are transported from source area to other locations [10].

Applications of pesticides on farmlands cause their infiltration into surface and ground waters via run off and percolation-related phenomena where they remain for a long time in the underground aquiver and strata. There, the pesticides possess greater capacity to resist biodegradation as they are not readily exposed to harsh weather conditions such as thermal and photo degradations that could synergize to accelerate biodegradation. Applications of pesticides on farmlands cause contamination of natural resources across different regions where they are being consumed directly with little or no purification [4]. The direct or indirect passage of OCPs from water bodies through the food chain has a tendency to pose adverse health effects to humans as well as a deviation from the normal state of health of aquatic and terrestrial organisms. Exposure to certain OCPs even at relatively low concentrations has been reported to have significant adverse effects on human health either in the short or long term due to their high level of toxicity [8]. Studies have also shown that there is high tendency for OCPs to be stored in fatty tissues of humans, animals and plants [11].

The chronic health effects from exposure to OCPs in contaminated drinking water and foodstuffs such as cancer, neurological damage, endocrine disruption, reproductive damages and lowering of immune system are evidences with direct link to the contents of water available in some regions for domestic use $[12,13]$.

The ecological monitoring of OCPs in a community where groundwater is the predominant source of potable water is important to assess the negative environmental impacts and potential health hazards to human through drinking such water. The present study was therefore aimed at determining the distribution of OCPs, characterizing the possible sources of the OCPs in the groundwater samples, and estimating the human health risks caused by the analyzed OCPs through consumption of the groundwater.

\section{Materials And Methods}

\subsection{The study area}

The study area, lle-lfe, an ancient town in Osun state, South-western Nigeria, is a moderately commercialized city that depends on the surrounding hinterland for most of its food supply. It is located between latitudes $7^{\circ} 28^{\prime} \mathrm{N}$ and $7^{\circ} 45^{\prime} \mathrm{N}$ and longitudes $4^{\circ} 30^{\prime} \mathrm{E}$ and $4^{\circ} 34^{\prime} \mathrm{E}$ (Figure 1) and has a population of 501,952 [14]. For domestic, public and commercial purposes, a larger percentage of the people of lleIfe makes use of groundwater drawn from hand-dug shallow wells and drilled boreholes, while others rely on streams. The occupation of most people in the community is farming and trading. Ile-Ife is a community that houses students of tertiary institutions, such as the Obafemi Awolowo University, the Polytechnic, lle-Ife and Oduduwa University, among others. 


\subsection{Chemicals and reagents used}

All the chemicals and reagents used in this research were of high purity and analytical grade obtained from dealer of Sigma-Aldrich (U.S.A.) in Nigeria. These reagents include silica gel (60-200 mesh size), anhydrous sodium sulphate of $99.5 \%$ purity, standard OCPs, dichloromethane (DCM), n-hexane and acetone. Dichloromethane and $\mathrm{n}$-hexane were distilled three times before use.

\subsection{Sample collection, storage and pre-treatment}

Sampling procedure was carried out according to APHA [15] standard methods for examination of water and wastewater. Groundwater samples were collected in triplicate inside clean amber coloured Winchester bottles ( $2.5 \mathrm{~L}$ capacity) after being washed with deionized water and the water samples. The groundwater samples were not filtered to separate suspended particles before extraction due to possibility of suspended particles having OCPs attached to them. The collected samples were stored at $4^{\circ} \mathrm{C}$ pending further analytical procedures.

\subsection{Extraction of OCPs and clean-up}

One litre $(1 \mathrm{~L})$ of groundwater sample was put in a $2 \mathrm{~L}$ separatory funnel and extracted (through liquidliquid extraction) in triplicates using $10 \mathrm{~mL}$ of doubly distilled dichloromethane (DCM) for each extraction batch. Periodical venting off of the built-up pressure was done intermittently at the initial stage followed by rigorous shaking which lasted for about 30 minutes. After each extraction, the organic phase was collected in a $50 \mathrm{~mL}$ amber-coloured vials. The three batches of extraction were pooled together and the volume of the extract was reduced to about $5 \mathrm{~mL}$ under a stream of air. For the clean-up experiment, a column of about $15 \mathrm{~cm}$ (length) $\times 1 \mathrm{~cm}$ (internal diameter) was plugged with glass wool at the bottom end and then packed with about $7 \mathrm{~g}$ activated silica gel prepared in a slurry form in DCM. About $2 \mathrm{~g}$ of anhydrous sodium sulfate was placed on top of the column to absorb any water in the sample or the solvent. The pre-elution was done with $15 \mathrm{~mL}$ of DCM without exposing the sodium sulfate layer to air so as to prevent cracking of the packed silica gel adsorbent. The reduced extracts were run through the column and allowed to sink below the sodium sulfate layer. Elution was done with $3 \times 10 \mathrm{~mL}$ portions of DCM. The eluents were collected and accompanying solvent was then evaporated to dryness under a stream of pure nitrogen.

\subsection{Qualitative and quantitative estimation of the organochlorine pesticides}

The OCPs extracted from the groundwater samples were analyzed with a Perkin Elmer Agilent 7890A Gas Chromatograph system equipped with Electron Capture Detector (GC-ECD) at the Nigeria Institute of Oceanography and Marine Research (NIOMR) Laboratory, Victoria Island, Lagos, Nigeria. The cleaned up and dried samples of the eluents were reconstituted with $1 \mathrm{~mL} n$-hexane. The separation was performed on a fused silica capillary column (DB-17, $30 \mathrm{~m}$ long $\times 0.25 \mathrm{~mm}$ internal diameter and film thickness of $0.25 \mu \mathrm{m})$. Carrier gas used was Nitrogen make up with Helium. Through a micro syringe, the injection of 1 $\mu \mathrm{L}$ of the purified eluents was performed in a splitless injection mode on the injection port at a flow rate 
of $2 \mathrm{~mL} \mathrm{~min}{ }^{-1}$ with the run time of $21.667 \mathrm{~min}$. The temperatures of the injector and detector were $250{ }^{\circ} \mathrm{C}$ and $290^{\circ} \mathrm{C}$ respectively. Oven temperatures programme started from $150^{\circ} \mathrm{C}$ and increased to $280^{\circ} \mathrm{C}$ at 6 ${ }^{\circ} \mathrm{C}$ per minute.

\subsection{Quality assurance and control}

Quality assurance and control were done according to method 8000B [16]. Instrument blanks were performed after calibration, and laboratory/extraction blanks were analyzed for each batch. No hydrocarbon residue was observed in blanks samples. Four calibration standard concentrations were used for each GC run, and correlation coefficients for the calibration curves were determined in triplicate. For recovery analysis, the stock solution of the OCP standards was diluted serially to obtain $10,20,30$, and $40 \mathrm{mg} \mathrm{L}^{-1}$. The recovery analysis was determined by spiking with the pesticide standard. The limits of detection and quantification of the organochlorine pesticide residues were determined according to Oyekunle et al[3].

$$
\text { Recovery }(\%)=\frac{C P 2-C P 1 \times 100}{C P}
$$

where, $\mathrm{CP}_{1}=$ concentration of pesticide residues in the sample, $\mathrm{CP}_{2}=$ concentration of pesticide residues in the spiked sample, $\mathrm{CP}=$ concentration of added pesticide standard.

\subsection{Risk assessment}

A health risk assessment model derived from USEPA [17] was used for the estimation of the carcinogenic and non-carcinogenic risk individuals are exposed to through the use of the groundwater. Carcinogenic risk (CR) was calculated from the relationships:

$$
\begin{aligned}
& \mathrm{EDI}=\frac{\mathrm{C} \times \mathrm{IR} \times \mathrm{EF} \times \mathrm{ED}}{\mathrm{BW} \times \mathrm{AT}} \\
& \mathrm{CR}=\mathrm{EDI} \times \mathrm{SF}
\end{aligned}
$$

where EDI = estimated daily intake in $\mu \mathrm{g} \mathrm{L}^{-1}$ day $^{-1}, \mathrm{C}=$ chemical concentration in the beverages in $\mathrm{ng} \mu \mathrm{L}^{-1}$, $\mathrm{IR}=$ beverage ingestion rate $\left(0.6 \mathrm{~L} \mathrm{day}^{-1}\right), \mathrm{EF}=$ exposure frequency $\left(365\right.$ days year $\left.{ }^{-1}\right), \mathrm{ED}=$ exposure duration (year) (for children: $E D=6$, for adults: $E D=70$ ), $B W=$ body weight (for children: $B W=14 \mathrm{~kg}$, for adults: $B W=70 \mathrm{~kg}$ ), AT = average lifespan (for children: $A T=2190$ days, for adults: $A T=25550$ days), SF $=$ slope factor $\left(\mathrm{kg}\right.$ day $\left.^{-1} \mathrm{mg}^{-1}\right)$.

To estimate non-carcinogenic risk, hazard quotient $(\mathrm{HQ})$ was calculated using the following equation:

$$
\mathrm{HQ}=\frac{\mathrm{EDI}}{\mathrm{RfD}}
$$


where RfD is the reference dose of the contaminant via oral exposure route $\left(\mathrm{mg} \mathrm{kg}^{-1} \mathrm{day}^{-1}\right)$.

The values of SF and RfD for OCPs are obtained from the USEPA Integrated Risk Information System [17].

\section{Results And Discussion}

\subsection{Results of recovery analysis}

To ascertain the accuracy and reliability of the result in this study, recovery analysis was performed and the results are presented in the Table 1 . The percentage recovery of the analyzed organochlorine compounds ranged from 75 to $91 \%$ indicating its accuracy and reliability in the determination of OCPs present in the samples. The standard deviations as well showed that the reproducibility of the results was satisfactory.

\subsection{Occurrence of OCPs in the analyzed groundwater samples}

The concentrations $\left(\mu \mathrm{g} \mathrm{L}^{-1}\right)$ of the sixteen organochlorine pesticides detected in the analyzed groundwater samples collected from lle-lfe are presented in Tables 2-4. The organochlorine pesticides determined in this study were grouped into three categories based on their chemical functional groups: Cyclodienes (dieldrin, endosulfan, endrin, heptachlor, aldrin and heptepoxide); Chlorinated cyclohexanes (a-HCB, $\beta-H C B, y-H C B, \delta-H C B$ toxaphene and mirex); and Diclorophenylethanes (methoxyclor, p,p'-DDD, $p, p^{\prime}-D D T$ and $\left.p, p^{\prime}-D D E\right)$.

\subsubsection{Concentrations $\left(\mu \mathrm{g} \mathrm{L}^{-1}\right)$ of Cyclodienes in the analyzed groundwater samples}

The concentrations of Cyclodienes in the investigated groundwater samples collected from lle-Ife are presented in Table 2. Remarkable differences in the mean concentration of the Cyclodienes in the groundwater samples were observed. The total mean concentrations of the Cyclodienes were $20.362 \pm 2.344 \mu \mathrm{g} \mathrm{L}^{-1}$ and ranged between $0.014 \pm 0.005-14.600 \pm 3.600 \mu \mathrm{g} \mathrm{L}^{-1}$. The profile of organochlorine pesticides in this category showed that the mean concentration of heptachlor $\left(14.600 \pm 3.600 \mathrm{~g} \mathrm{~L}^{-1}\right)$ was higher than the maximum residue limit (MRL) of $0.03 \mu \mathrm{g} \mathrm{L}^{-1}$ in drinking water [18]. These concentrations required that the water be subjected to some treatments to lower the amounts of heptachlor in the groundwater because the groundwater was being used in the study area for drinking and other domestic purposes. Also, heptachlor epoxide, a metabolite of heptachlor, was detected at significantly lower concentration of $0.019 \pm 0.001 \mu \mathrm{g} \mathrm{L}^{-1}$ in the samples. Heptachlor epoxide has been known to be more toxic than heptachlor in terms of its insecticidal actions; it is usually not available for direct use as its presence in the environment has been linked with the application of heptachlor which undergoes metabolic degradation to form the more potent heptachlor epoxide that could be detected in plant and insect tissues. A prolong exposure to heptachlor epoxide has been associated with damage to the liver and central nervous system toxicity [18]. Also, the levels of dieldrin $\left(0.014 \pm 0.005 \mu \mathrm{g} \mathrm{L}^{-1}\right)$ and aldrin $\left(0.070 \pm 0.008 \mu \mathrm{g} \mathrm{L}^{-1}\right)$ recorded in the groundwater sample were greater than MRLs of $0.01 \mu \mathrm{g} \mathrm{L}^{-1}$ in 
drinking water [18]. Levels of endrin which is an alicyclic chlorinated with capacity to be rapidly converted into an epoxide was observed at mean concentration of $0.018 \pm 0.008 \mu \mathrm{g} \mathrm{L}^{-1}$. In another study carried out by El Bouraie et al [19] on groundwater, a lower concentration of $\Sigma$ cyclodienes (aldrin, dieldrin, endrin, heptachlor, heptachlor epoxide and endosulfan) which ranged from 0.001 to $0.074 \mu \mathrm{g} \mathrm{L}^{-1}$ was observed. Ogunlowo [20] also reported concentration range of ND to $2150 \mathrm{ng} \mathrm{L}^{-1}$ for lindane, heptachlor, endrin, aldrin and dieldrin in a study of OCPs levels in 9 rivers in Ondo state. This is an indication that the present investigation showed a comparatively high concentration of cyclodienes in the analyzed ground waters. Occupational pesticide exposure to dieldrin has been reported to increase the risk of Parkinson's disease [21]. Also, endosulfan has been known to act as endocrine disrupting chemicals (EDCs) thereby affecting the endocrine system by interference with molecular circuitry [22].

\subsubsection{Concentrations $\left(\mu \mathrm{g} \mathrm{L}^{-1}\right)$ of Dichlorodiphenylethanes in the groundwater samples}

Four organochlorine compounds in the category of dichlorodiphenylethanes group were detected in the groundwater samples as presented in Table 3. These are methoxychlor, p,p'-DDD, p,p'-DDE and p,p'-DDT with range of concentrations between ND (not detected) $-56.02 \pm 5.01 \mathrm{~g} \mathrm{~L}^{-1}$. The methoxychlor congener was the predominant dichlorodiphenylethanes pesticide in the analyzed groundwater with total mean concentration of $12.600 \pm 2.200 \mu \mathrm{g} \mathrm{L}^{-1}$. In comparison with other sites, significantly higher concentrations of methoxychlor were observed at sites $F\left(20.000 \pm 2.000 \mu \mathrm{g} \mathrm{L}^{-1}\right)$ and $\mathrm{J}\left(56.001 \pm 5.020 \mu \mathrm{g} \mathrm{L}^{-1}\right), \mathrm{p}, \mathrm{p}^{\prime}-\mathrm{DDD}$ was detected only at site $E$ while $p, p^{\prime}-D D E$ was not detected in any of the groundwater samples. Dichlorodiphenylethanes detected in this study were found at relatively lower concentrations in comparison to other OCPs detected in the groundwater samples. This could be due to their physical and biological characteristics like lower water solubility and rate of degradation [12, 23]. These concentrations were lower than those reported for some investigations in rivers from Niger Delta region and Lagos Lagoon, Nigeria where a widespread distribution of OCPs in sediment was more pronounced [6, 24]. EI Bouraie et al [19] recorded a varied concentration of $\Sigma D D T$ from 0.00 to $1.126 \mathrm{\mu g} \mathrm{L}^{-1}$ and from 0.003 to $0.049 \mu \mathrm{L}^{-1}$ for surface and groundwater respectively. In terms of health hazard, methoxychlor's toxicity includes potential endocrine disrupting property with major effects on reproduction due to their capacity of subtle toxic effects on the body's hormonal systems, recent observations in rats showed it possibility in promoting epigenetic transgenerational inheritance of heart diseases [25]. Reports have it that serum concentrations of $p-p^{\prime}-D D E$ and $p, p^{\prime}-D D D$ have a direct link to abnormality in thyroid hormone levels [26]. Prenatal exposure to $\mathrm{p}, \mathrm{p}^{\prime}-\mathrm{DDE}$ has also been reported to cause disappearance of neuronal development after 12 months of infant age [27].

\subsubsection{Concentrations $\left(\mu \mathrm{g} \mathrm{L}^{-1}\right)$ of chlorinated benzene in the groundwater samples}

Chlorinated benzenes consist the different isomers of Hexachlorobenzene (HCB) which have been known to increase the incidences of liver and thyroid cancers. The mean concentration of all the hexachlorobenzene isomers in the analyzed groundwater samples in comparison with respective MRLs are presented in Table 4. The mean concentrations of detected chlorinated benzene ranged from 
$0.012 \pm 0.001-8.100 \pm 2.100 \mu \mathrm{g} \mathrm{L}^{-1}$ in which the most prominent $\mathrm{HCB}$ isomer detected in the sample is a$\mathrm{HCB}$ with mean concentration of $0.019 \pm 0.001 \mathrm{~g} \mathrm{~L} \mathrm{~L}^{-1}$. $\mathrm{Y}-\mathrm{HCB}$ and $\delta-\mathrm{HCB}$ isomer recorded mean concentrations of $0.013 \pm 0.001 \mu \mathrm{g} \mathrm{L}^{-1}$ and $0.014 \pm 0.002 \mathrm{\mu g} \mathrm{L}^{-1}$ respectively, while $\beta$-HCB showed the lowest concentration at $0.011 \pm 0.002 \mu \mathrm{g} \mathrm{L}^{-1}$. these concentrations were found to be relatively higher than the recommended $0.01 \mathrm{~g} \mathrm{~L}^{-1} \mathrm{MRLs}$ in drinking water [18]. Similar studies carried out in Ogbese river in Ekiti showed lower concentration of this OCPs congeners [28]. However, Ogbeide et al [29] detected higher levels than that reported in this study for $\triangle$ HCBs and $\triangle D D T s$ in sediments from 3 water bodies (Illushi, Ogbese, and Owan River) situated in Niger Delta, Nigeria. The average concentration of $\triangle \mathrm{HCBs}$ at Illushi, Ogbese and Owan River were $4089 \mu \mathrm{g} \mathrm{kg}^{-1}, 4080 \mu \mathrm{g} \mathrm{kg}^{-1}$ and $4900 \mu \mathrm{g} \mathrm{kg}^{-1}$ खCBs while खDDTs were 970 $\mu \mathrm{g} \mathrm{kg}^{-1}, 1160 \mu \mathrm{g} \mathrm{kg}^{-1}$ and $930 \mu \mathrm{g} \mathrm{kg}^{-1}$ for the 3 investigated rivers respectively. Exposure to different isomers of HCBs has been reported as potential risk factor for gallstone disease in humans. Also, possible neurotoxic effects of these compounds were reported on early psychomotor development even at relatively low doses [30]. A study conducted recently in China indicated a decrease in birth weight of infants that are exposed to $\beta-B H C, H C B$ and mirex during prenatal stage [31]. The total concentrations of the three categories of OCPs analyzed in the studied groundwater samples as presented in Figure 2 followed the decreasing trend: Cyclodienes $>$ Diclorophehylethanes $>$ Chlorinated benzene/Cyclohexanes and this trend corresponded to that obtained for agricultural soil of Oke-Osun farm settlement, Osogbo, Nigeria [3]. These concentrations are an indication that the studied environment might have been exposed to pesticides contamination via water runoff and improper application of pesticides. However, this is a key concern as the entire community and principal users of the groundwater may be exposed to these pesticides which have capacity to bioaccumulate over the layers and if not accurately monitored could lead to major health issues.

\subsection{Source identification of OCPs}

\subsubsection{Composition of OCPs as markers}

The concentrations of the OCPs detected in an environmental sample can be used as markers to reveal the possible pollution sources in samples. Different ratios have been adopted in the literature to identify the probable source(s) of the analyzed OCPs in the groundwater [32]. Endrin is a metabolitic product of aldrin used to control soil pests such as termites. Ile-Ife environment has a large population of termites. In this study, the concentration of aldrin $\left(0.070 \pm 0.002 \mu \mathrm{g} \mathrm{L}^{-1}\right)$ is more than endrin $\left(0.018 \pm 0.008 \mu \mathrm{g} \mathrm{L}^{-1}\right)$ indicating a fresh application of aldrin to soils around the vicinity of the community where the groundwater samples were collected. It could also be an indication of various anthropogenic contaminations from indiscriminate disposal of used pesticide containers, leaching of applied pesticides, aerial deposition, transfer of pesticides from improperly cleaned utensils used for pesticide applications, and so on. Therefore, the source of the analyzed pesticides might be from fresh application and not necessarily from historical residues [33]. Heptachlors (heptachlor and heptachlor epoxide) have found their use essentially against soil insects and plasmodium. This composition can as well be used as markers for the sources of the OCPs analyzed in the groundwater samples. Heptachlor epoxide is a 
known product of the metabolic activities of heptachlor and is relatively a more stable derivative than heptachlor. The high concentration of heptachlor $\left(14.600 \pm 3.60 \mu \mathrm{g} \mathrm{L}^{-1}\right)$ than heptachlor epoxide $\left(0.019 \pm 0.001 \mu \mathrm{g} \mathrm{L}^{-1}\right)$ is an indication of a fresh source of the pesticide which spread into the study area possibly due to runoff or dry and wet depositions. The concentration levels of OCPs in the investigated groundwater suggested recent use of the recorded pesticides despite being banned several years ago [34].

\subsubsection{Correlation matrix of the organochlorine pesticides in the analyzed groundwater}

The result of the correlation matrix analysis carried out on the concentration of OCPs determined in the groundwater samples is presented in Table 5 . Values in bold figures indicate significant and strong positive correlations supporting a common origin of the OCPs concerned and this was confirmed from the source identification assessment.

\subsection{Human health risk assessment}

The human health risk assessment of the OCPs in the groundwater samples upon consumption by children and adults are presented in Tables 6 and 7 respectively. The health risks were assessed in terms of non-carcinogenic and carcinogenic health risks. The non-carcinogenic health risks were evaluated by hazard quotients (HQs) emanating from the consumption of the groundwaters. In adults, HQs greater than 1 are dieldrin (7.942), toxaphene (1.157), endrin (1.733), heptachlor (83.428), aldrin (66.380), heptachlor epoxide (108.131), a-BHC (1.209), and $y$-BHC (4.447). In children, HQs greater than 1 were observed for dieldrin (19.857), Toxaphene (2.892), endrin (4.333), heptachlor (208.571), aldrin (165.952), Heptachlor epoxide (270.329), a-BHC (3.023), ס-HCB (1.651), and y-HCB (11.119). Hazard quotients greater than 1 is an indication that there are non-carcinogenic health risks associated with the consumption of the groundwater of the study area. Relatively higher HQs observed in children as opposed to adults are consistent with the assertion that children are the more vulnerable population to the analyzed environmental contaminants.

The carcinogenic health risks were evaluated using cancer risks (CR) accrued to the consumption of the groundwaters. USEPA-defined risk threshold value is $10^{-6}$. In both adults and children, CR values greater than $10^{-6}$ were observed for dieldrin, toxaphene, heptachlor, aldrin, heptachlor epoxide, $a-H C B, \beta-H C B$, and $\mathrm{Y}$-HCB. The carcinogenic health risks posed to adults and children from the consumption of the ground waters is significant.

\section{Conclusion}

The result of the investigation of organochlorine pesticides in the groundwater samples showed that the concentration of most of the analyzed OCPs were found above the maximum acceptable levels for drinking water. Most rural communities are often exposed to pesticides pollution as a result of indiscriminate use and application of pesticides on farm lands to improve crop yields by controlling pest and disease. The presence of analyzed pesticides in the groundwater samples suggests the runoff of 
applied pesticides on farmlands to the underground aquifer of the community. The assessment of the analyzed OCPs in the investigated groundwater revealed that there were associated carcinogenic and non-carcinogenic health risks for both adults and children to the use of the groundwater either for drinking or other essential purpose owing to the high hazard quotient. It was observed that children consuming this water are more vulnerable than adult but however continuous monitoring of the groundwater is thereby needed to prevent the community from being exposed to detrimental effects of organochlorine pesticides both now or the nearest future.

\section{Declarations}

\section{Availability of data and materials}

Not applicable

\section{Competing Interests}

The authors declare that they have no conflict of interest

\section{Funding}

The research did not receive any specific funding

\section{Author's contributions}

JAO designed the experiment. AOA collected the samples and performed the laboratory experiments. AOA and OTO wrote the manuscript. JAO critically revised the manuscript. All authors read and approved the final manuscript.

\section{Acknowledgements}

The authors thank Obafemi Awolowo University, Ile-Ife, Nigeria for providing an enabling environment for the research.

\section{References}

[1] Olisah C, Adeniji AO, Okoh O0, Okoh Al. Occurrence and risk evaluation of organochlorine contaminants in surface water along the course of Swartkops and sundays river estuaries, eastern Cape province, South Africa. Environ. Geochem. Health 2019b;1-25.

[2] Akinnifesi TA, Asubiojo Ol, Amusan AA. Effects of fungicide residue on the physico-chemical characteristics of soils of a major cocoa-producing area of Nigeria. Science of Total Environment. 2006;366:876-879. 
[3] Oyekunle JAO, Ogunfowokan AO, Torto N, Akanni MS. Determination of organochlorine pesticides in the agricultural soil of Oke-Osun farm settlement, Osogbo, Nigeria, Environ. Monit. Assess. 2011;177: 51 61.

[4] Solomon A. Concentration of organophosphorous pesticide residues in water and sediment samples from River Ilaje, Nigeria. American Chemical Science Journal. 2016;11:1-9.

[5] World Health Organization (WHO) 2004. Poison on DDT use in disease vector control under the Stickholm Convention on Persistent organic pollutants. WHO Regional Office for Americans/Pan American Sanitary Bureau (AMRO/PAHO) 525, 23 RD Street, N.W., Washington, DC 20037, USA; 2004.

[6] Ize-lyamu OK, Abia IO, Egwakhide PA. Concentrations of residues from organochlorine pesticide in water and fish from some rivers in Edo State, Nigeria. International Journal of Physical Science. 2007;2:237-241.

[7] Adeyemi D, Ukpo G, Anyakora C, Unyimadu JP. Organochlorine pesticide residues in fish samples from Lagos lagoon, Nigeria. American Journal Environmental Science. 2008;4(6):649-653.

[8] Sosan MB, Akingbohungbe AE, Ojo IAO, Durosinmi MA. Insecticide residue in the blood serum and domestic water source of cacao farmers in southwestern Nigeria. Chemosphere Journal. 2008;72:781784.

[9] Adeleye AO, Sosan MB, Oyekunle JAO. Dietary exposure assessment of organochlorine pesticides in two commonly grown leafy vegetables in South-western, Nigeria. Heliyon. 2019;4:e01895. https://doi.org/10.1016/j. heliyon.2019.e01895

[10] Kaakeh W, Maraqa M, Hasan M, El Marzouqi M. Management of Pesticides in the United Arab Emirates. Emirate Journal of Agricultural Science. 2004;16(1):15-31.

[11] Bentzen TW, Follman EH, Amstrup SC, York GS, Woller MJ, Muir DCG, O'Hara TM. Dietary biomagnification of organochlorine contaminant in Alaskan polar bears. Canadian Journal Zool. 2008;86:177-191

[12] Le Maire G, Terouanne B, Mauvais P, Michel S, Rahmania R. Effect of organochlorine pesticides on human androgen receptor activation in vitro. Journal of Toxicology and Applied Pharmacology. 2004;196:235- 246.

[13] Agency for Toxic Substance and Disease Registry (ATSDR) 2005. Toxicological Profile for Hexachlorocyclohexane. Atlanta, GA: U.S. Department of Health and Human Service; 2005.

[14] Ajala OA, Olayiwola AM. An Assessment of the Growth of Ile-Ife, Osun State Nigeria, Using MultiTemporal Imageries. Journal of Geography and Geology. 2013;5(2): 43-54. 
[15] APHA. 2005. Standard methods for the examination of water and waste water. 21st edition. Washington DC, American Public Health Association, American Water Works Association and Water Works Association and Water Environment Federation, USA; 2005.

[16] US Environmental Protection Agency (USEPA) 2007. Method 3510, Revision C, Washington DC: USEPA; 2007.

[17] IRIS (Integrated Risk Information System). 2005. US Environmental Protection Agency, Cincinnati, OH. Accessed at http://www.epa.gov/iris, 9; 2005.

[18] World Health Organization (WHO) 2011. Guidelines for drinking water quality. Fourth Edition @ World Health Organization. Pp.179-191,307-443; 2011.

[19] El Bouraie MM, El Barbary AA, Yehia MM, Motawea EA. Heavy metal concentrations in surface river water and bed sediments at Nile Delta in Egypt. Suo-Mires \& peat, 2011;61:1-12.

[20] Ogunlowo SO. Priority chemical pollutants in some rivers along the cocoa growing area of Ondo State. [MSc. Thesis]. Department of Chemistry, University of Ibadan, Nigeria; 1991.

[21] Steenland K, Mora AM, Barr DB, Juncos J, Roman N, Wesseling C. Organochlorine chemicals and neurodegeneration among elderly subjects in Costa Rica. Environmental Research. 2014;134:205-9.

[22] Sohail E, Waseem A, Chae WL, Jong JL, Imitiaz H. Endocrine Disrupting Pesticides: A Leading Cause of Cancer among Rural People in Pakistan. Experimental Oncology. 2004;26(2): 98-105.

[23] Yang XL, Wang SS, Bian YR, Chen F, Yu GF, Gu G. Dicofol application resulted in high DDTs residue in cotton fields from northern Jiangsu province, China. Journal of Hazard Mater. 2007;150:92-8.

[24] Lawrence E, Thomas I, Isioma T. Distribution of propoxur in water, sediment and fish from Warri River Niger Delta, Nigeria. Turk. Journal of Biochemistry. 2009;34:121-7.

[25] US Environmental Protection Agency (USEPA) (2019). Method 3510, Revision C, Washington DC: USEPA; 2019.

[26] Meeker JD, Altshul L, Hauser R. Serum PCBs, p,p/ -DDEand HCB predict thyroid hormone levels in men. Journal of Environmental Research. 2007;104:296-304.

[27] Torres-Sanchez L, Schnaas L, Cebrian ME, Hernandez M, del C, Valencia EO, Hernandez RMG, LopezCarrillo L. Prenatal Dichlorodiphenyldichloroethylene (DDE) exposure and neurodevelopment: A follow-up from 12 to 30 months of age. Neurotoxicology. 2009;30(6): 1162-5.

[28] Ibigbami OA, Adebawore AA. Persistent Organochlorine Pesticide Residues in Some Selected Cocoa Beverages in Nigeria. Beverages. 2017;3(60):1-7. doi:10.3390/beverages3040060. 
[29] Ogbeide O, Tongo I, Ezemonye L. Assessing the distribution and human health risk of organochlorine pesticide residues in sediments from selected rivers. Journal of Chemosphere. 2016;144:1319-1326.

[30] Forns J, Lertxundi N, Aranbarri A, Murcia M, Gascon M, Martinez D, et al. Prenatal exposure to organochlorine compounds and neuropsychological development up to two years of life. Journal of Environment International. 2012;45:72-7.

[31] Guo H, Jin Y, Cheng Y, Leaderer B, Lin S, Holford TR, et al. Prenatal exposure to organochlorine pesticides and infant birth weight in China. Chemosphere journal. 2014;110:17.

[32] Zhou RB, Zhu LZ, Yang K, Chen YY. Distribution of organochlorine pesticides in surface water and sediments from Qiantang River, East China. Journal of Hazard Matter. 2006;137:68-75.

[33] Wu L, Zhou X, Zhao D, Feng T, Zhou J, Sun T, Wang J, Wang C. Seasonal variation and exposure risk assessment of pesticide residues in vegetables from Xinjiang Uygur Autonomous Region of China during 2010-2014. Journal of Food Composition and Analysis. 2017;58:1-9. doi:10.1016/j.jfca.2016.12.025

[34] Olisah C, Okoh 00, Okoh Al. Global evolution of organochlorine pesticides research in biological and environmental matrices from 1992 to 2018: a bibliometric approach. Emerg. Contam. 2019a;5:157-167.

\section{Tables}

Table 1: Response Factor and Recovery for OCPs

\begin{tabular}{lcc}
\hline OCPs & Response Factor & Percent Recovery (\%) \\
\hline Dieldrin & 0.806 & 80.24 \\
Endrin & 0.691 & 89.15 \\
Heptachlor & 0.847 & 75.24 \\
p,p'-DDT & 0.711 & 87.50 \\
$\alpha-$ HCB & 0.615 & 90.75 \\
\hline
\end{tabular}


Table 2: Concentrations ( $\mu \mathrm{g} / \mathrm{L}$ ) of Cyclodiene in the Groundwater samples of Ile-Ife

\begin{tabular}{|c|c|c|c|c|c|c|c|}
\hline Location & Dieldrin & Endosulfan & Endrin & Heptachlor & Aldrin & $\begin{array}{c}\text { Hepachlor } \\
\text { epoxide }\end{array}$ & Total OCP Burden \\
\hline A & $0.018 \pm 0.001$ & $0.010 \pm 0.010$ & $0.013 \pm 0.010$ & $7.000 \pm 1.000$ & $0.051 \pm 0.010$ & $0.018 \pm 0.010$ & $7.110 \pm 1.650$ \\
\hline B & $0.011 \pm 0.010$ & $0.007 \pm 0.002$ & $0.010 \pm 0.005$ & $4.000 \pm 1.000$ & $0.380 \pm 0.130$ & $0.020 \pm 0.010$ & $4.482 \pm 1.540$ \\
\hline $\mathrm{C}$ & $0.008 \pm 0.001$ & $0.010 \pm 0.005$ & $0.007 \pm 0.001$ & $8.000 \pm 1.200$ & $0.071 \pm 0.010$ & $0.015 \pm 0.005$ & $8.111 \pm 1.720$ \\
\hline $\mathrm{D}$ & $0.005 \pm 0.001$ & $0.013 \pm 0.005$ & $0.009 \pm 0.002$ & $11.00 \pm 1.000$ & $0.054 \pm 0.010$ & $0.012 \pm 0.010$ & $11.093 \pm 1.630$ \\
\hline $\mathrm{E}$ & $0.007 \pm 0.002$ & $0.011 \pm 0.010$ & $0.003 \pm 0.001$ & $5.000 \pm 1.000$ & $0.039 \pm 0.010$ & $0.024 \pm 0.010$ & $5.084 \pm 1.530$ \\
\hline $\mathrm{F}$ & $0.022 \pm 0.010$ & $0.018 \pm 0.010$ & $0.026 \pm 0.005$ & $18.000 \pm 2.000$ & $0.018 \pm 0.005$ & $0.015 \pm 0.010$ & $18.099 \pm 4.050$ \\
\hline G & $0.016 \pm 0.010$ & $0.029 \pm 0.005$ & $0.016 \pm 0.010$ & $14.000 \pm 1.000$ & $0.036 \pm 0.010$ & $0.025 \pm 0.011$ & $14.122 \pm 3.550$ \\
\hline $\mathrm{H}$ & $0.021 \pm 0.010$ & $0.036 \pm 0.010$ & $0.030 \pm 0.010$ & $26.000 \pm 5.000$ & $0.017 \pm 0.010$ & $0.017 \pm 0.005$ & $26.121 \pm 6.040$ \\
\hline I & $0.009 \pm 0.002$ & $0.026 \pm 0.005$ & $0.021 \pm 0.005$ & $19.000 \pm 3.000$ & $0.013 \pm 0.010$ & $0.029 \pm 0.010$ & $19.098 \pm 7.030$ \\
\hline J & $0.022 \pm 0.010$ & $0.031 \pm 0.010$ & $0.047 \pm 0.010$ & $34.000 \pm 5.000$ & $0.018 \pm 0.005$ & $0.016 \pm 0.010$ & $34.134 \pm 6.050$ \\
\hline Range & $0.005-0.022$ & $0.007-0.036$ & $0.003-0.047$ & $4.000-34.000$ & $0.013-0.380$ & $0.012-0.029$ & $4.482-34.132$ \\
\hline Mean $\pm S D$ & $0.014 \pm 0.005$ & $0.019 \pm 0.005$ & $0.018 \pm 0.008$ & $14.600 \pm 3.600$ & $0.070 \pm 0.002$ & $0.019 \pm 0.001$ & $14.760 \pm 2.344$ \\
\hline MRL & 0.01 & 0.10 & 0.006 & 0.003 & 0.01 & 0.003 & \\
\hline
\end{tabular}

MRL = Maximum residue levels (WHO, 2011)

Table 3: Concentrations $(\mu \mathrm{g} / \mathrm{L}$ ) of Dichlorophenylethanes in the groundwater samples of Ile-lfe MRL = Maximum residue levels (WHO, 2011)

\begin{tabular}{cccccc}
\hline Location & Methoxychlor & $\mathbf{p}$, $\mathbf{p}^{\prime}$-DDD & $\mathbf{p}$, $\mathbf{p}^{\prime}$-DDT & $\mathbf{p}$, $\mathbf{p}^{\prime}$-DDE & Total OCP Burden \\
\hline A & $6.000 \pm 1.000$ & ND & $0.011 \pm 0.001$ & ND & $6.011 \pm 1.002$ \\
B & $4.000 \pm 1.500$ & ND & BDL & ND & $4.000 \pm 1.501$ \\
C & $8.000 \pm 1.700$ & ND & BDL & ND & $8.000 \pm 1.702$ \\
D & $5.000 \pm 2.000$ & ND & BDL & ND & $5.000 \pm 2.050$ \\
E & $2.003 \pm 0.500$ & $0.105 \pm 0.002$ & BDL & ND & $2.105 \pm 0.102$ \\
F & $20.000 \pm 2.000$ & ND & $0.018 \pm 0.005$ & ND & $20.018 \pm 2.010$ \\
G & $9.000 \pm 1.000$ & ND & BDL & ND & $9.000 \pm 1.010$ \\
H & $13.001 \pm 2.500$ & ND & $0.007 \pm$ & ND & $13.007 \pm 2.504$ \\
I & $3.000 \pm 0.500$ & ND & BDL & ND & $3.000 \pm 0.501$ \\
J & $56.001 \pm 5.020$ & ND & $0.025 \pm 0.001$ & ND & $56.025 \pm 5.010$ \\
Range & $2.003-56.001$ & ND-0.105 & BDL-0.025 & ND & $4.000-56.025$ \\
Mean $\pm S D$ & $12.600 \pm 2.200$ & ND & $0.004 \pm 0.001$ & ND & $12.604 \pm 1.207$ \\
MRL & 0.5 & 0.5 & 0.5 & 0.5 & \\
\hline
\end{tabular}


Table 4: Concentrations $(\mu \mathrm{g} / \mathrm{L}$ ) of Chlorinated benzene/Cyclohexane in the groundwater samples of Ile-Ife

\begin{tabular}{cccccccc}
\hline Location & $\alpha-\mathrm{HCB}$ & $\beta-\mathrm{HCB}$ & $\gamma$-HCB & $\delta$-HCB & Toxaphene & Mirex & Total OCP Burden \\
\hline A & $0.014 \pm 0.010$ & $0.002 \pm 0.001$ & $0.003 \pm 0.001$ & $0.012 \pm 0.010$ & $1.000 \pm 0.600$ & $0.007 \pm 0.002$ & $1.038 \pm 0.024$ \\
B & $0.010 \pm 0.005$ & $0.001 \pm 0.001$ & $0.003 \pm 0.001$ & $0.008 \pm 0.002$ & $3.000 \pm 0.500$ & $0.004 \pm 0.001$ & $3.026 \pm 0.01$ \\
C & $0.013 \pm 0.010$ & $0.003 \pm 0.001$ & $0.004 \pm 0.001$ & $0.011 \pm 0.001$ & $1.000 \pm 0.500$ & $0.009 \pm 0.002$ & $1.040 \pm 0.032$ \\
D & $0.009 \pm 0.003$ & $0.001 \pm 0.001$ & $0.002 \pm 0.001$ & $0.007 \pm 0.001$ & $2.000 \pm 0.600$ & $0.010 \pm 0.005$ & $2.029 \pm 0.008$ \\
E & $0.008 \pm 0.002$ & $0.001 \pm 0.001$ & $0.006 \pm 0.002$ & $0.019 \pm 0.005$ & $2.000 \pm 0.500$ & $0.008 \pm 0.002$ & $2.042 \pm 0.01$ \\
F & $0.022 \pm 0.010$ & $0.019 \pm 0.011$ & $0.015 \pm 0.004$ & $0.030 \pm 0.001$ & $17.000 \pm 2.000$ & $0.019 \pm 0.001$ & $17.105 \pm 0.051$ \\
G & $0.013 \pm 0.010$ & $0.025 \pm 0.012$ & $0.028 \pm 0.001$ & $0.021 \pm 0.015$ & $15.000 \pm 2.500$ & $0.012 \pm 0.005$ & $15.099 \pm 0.057$ \\
H & $0.017 \pm 0.010$ & $0.018 \pm 0.011$ & $0.017 \pm 0.001$ & $0.009 \pm 0.002$ & $11.000 \pm 1.000$ & $0.021 \pm 0.001$ & $11.082 \pm 0.043$ \\
I & $0.028 \pm 0.012$ & $0.022 \pm 0.011$ & $0.031 \pm 0.001$ & $0.013 \pm 0.001$ & $18.000 \pm 4.000$ & $0.011 \pm 0.002$ & $18.105 \pm 0.048$ \\
J & $0.051 \pm 0.010$ & $0.0150 \pm 0.005$ & $0.019 \pm 0.002$ & $0.009 \pm 0.002$ & $11.000 \pm 1.000$ & $0.020 \pm 0.001$ & $11.114 \pm 0.038$ \\
Range & $0.008-0.028$ & $0.001-0.025$ & $0.002-0.031$ & $0.007-0.030$ & $1.000-18.000$ & $0.004-0.021$ & $1.038-18.105$ \\
Mean \pm SD & $0.019 \pm 0.001$ & $0.011 \pm 0.002$ & $0.013 \pm 0.001$ & $0.014 \pm 0.002$ & $8.100 \pm 2.100$ & $0.012 \pm 0.010$ & $8.169 \pm 0.09$ \\
MRL & 0.01 & 0.01 & 0.01 & 0.01 & 0.01 & 0.01 & \\
\hline
\end{tabular}

MRL = Maximum residue levels (WHO, 2011)

Table 5: Correlation Matrix of the Organochlorine Pesticides in the sampled Groundwater

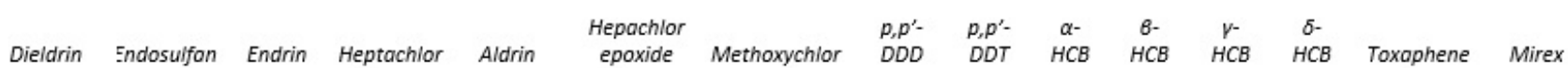

\begin{tabular}{|c|c|c|c|c|c|c|c|c|c|c|c|c|c|c|}
\hline Dieldrin & 1 & & & & & & & & & & & & & \\
\hline Endosulfan & 0.568 & 1 & & & & & & & & & & & & \\
\hline Endrin & 0.779 & 0.767 & 1 & & & & & & & & & & & \\
\hline Heptachlor & 0.651 & 0.870 & 0.957 & 1 & & & & & & & & & & \\
\hline Aldrin & -0.247 & -0.515 & -0.337 & -0.495 & 1 & & & & & & & & & \\
\hline $\begin{array}{l}\text { Hepachlor } \\
\text { epoxide }\end{array}$ & -0.196 & 0.196 & -0.151 & -0.114 & -0.004 & 1 & & & & & & & & \\
\hline Methoxychlor & 0.641 & 0.492 & 0.872 & 0.797 & -0.253 & -0.336 & 1 & & & & & & & \\
\hline $\mathrm{p}, \mathrm{p}^{\prime}-\mathrm{DDD}$ & -0.365 & -0.271 & -0.403 & -0.345 & -0.097 & 0.322 & -0.230 & 1 & & & & & & \\
\hline$p, p^{\prime}-D D T$ & 0.813 & 0.344 & 0.816 & 0.678 & -0.308 & -0.406 & 0.866 & -0.235 & 1 & & & & & \\
\hline$\alpha-\mathrm{HCB}$ & 0.539 & 0.576 & 0.896 & 0.848 & -0.326 & -0.023 & 0.887 & -0.284 & 0.766 & 1 & & & & \\
\hline$\beta-H C B$ & 0.537 & 0.841 & 0.609 & 0.668 & -0.460 & 0.391 & 0.306 & -0.342 & 0.260 & 0.468 & 1 & & & \\
\hline$\gamma-\mathrm{HCB}$ & 0.345 & 0.809 & 0.538 & 0.617 & -0.434 & 0.603 & 0.254 & -0.220 & 0.130 & $\begin{array}{c}0.507 \\
-\end{array}$ & 0.946 & 1 & & \\
\hline$\delta-\mathrm{HCB}$ & 0.293 & 0.030 & -0.017 & -0.050 & -0.324 & 0.214 & -0.035 & 0.2456 & 0.187 & 0.066 & 0.431 & 0.306 & 1 & \\
\hline Toxaphene & 0.491 & 0.737 & 0.606 & 0.640 & -0.390 & 0.393 & 0.301 & -0.305 & 0.304 & 0.504 & 0.959 & 0.912 & 0.499 & 1 \\
\hline Mirex & 0.726 & 0.803 & 0.843 & 0.899 & -0.584 & -0.271 & 0.682 & -0.244 & 0.678 & 0.623 & 0.661 & 0.499 & 0.230 & 0.633 \\
\hline
\end{tabular}


Table 6: Health Risk Assessment of OCPs in Groundwater upon Consumption by Adults

\begin{tabular}{lllllll}
\hline OCPs & Mean & EDI & RfD & HQ & SF & CR \\
\hline Dieldrin & 0.0139 & 0.000397 & $5.00 \mathrm{E}-05$ & 7.942 & 16 & 0.006 \\
Endosulfan & 0.0191 & 0.000546 & $6.00 \mathrm{E}-03$ & 0.090 & - & - \\
Toxaphene & 8.1 & 0.231429 & $2.00 \mathrm{E}-01$ & 1.157 & 1.1 & 0.254 \\
Endrin & 0.0182 & 0.00052 & $3.00 \mathrm{E}-04$ & 1.733 & - & - \\
Heptachlor & 14.6 & 0.417143 & $5.00 \mathrm{E}-03$ & 83.428 & 4.5 & 1.877 \\
Aldrin & 0.0697 & 0.001991 & $3.00 \mathrm{E}-05$ & 66.380 & 17 & 0.033 \\
Heptachlor epoxide & 0.0492 & 0.001406 & $1.30 \mathrm{E}-05$ & 108.131 & 9.1 & 0.012 \\
$\alpha$-HCB & 0.0127 & 0.000363 & $3.00 \mathrm{E}-04$ & 1.209 & 1.3 & 0.001 \\
$\delta$-HCB & 0.0185 & 0.000529 & $8.00 \mathrm{E}-04$ & 0.660 & 1.6 & 0.003 \\
$\beta$-HCB & 0.0503 & 0.001437 & $8.00 \mathrm{E}-03$ & 0.179 & 1.8 & 0.002 \\
Y-HCB & 0.0467 & 0.001334 & $3.00 \mathrm{E}-04$ & 4.447 & 1.1 & 0.001 \\
Methoxychlor & 12.6 & 0.36 & $5.00 \mathrm{E}-03$ & 72 & - & - \\
Mirex & 0.0121 & 0.000346 & $1.80 \mathrm{E}+01$ & $1.92 \mathrm{E}-05$ & - & - \\
\hline
\end{tabular}

* EDI = estimated daily intake, $\mathrm{RfD}$ = oral reference dose, $\mathrm{HQ}=$ hazard quotient, $\mathrm{SF}=$ slope factor and $\mathrm{CR}=$ Carcinogenic risk, NA $=$ Not available 
Table 7: Health Risk Assessment of OCPs in Groundwater upon Consumption by Children

\begin{tabular}{|c|c|c|c|c|c|c|}
\hline OCPs & Mean & EDI & RfD & HQ & SF & CR \\
\hline Dieldrin & 0.0139 & 0.000993 & $5.00 \mathrm{E}-05$ & 19.857 & 16 & 0.015 \\
\hline Endosulfan & 0.0191 & 0.001364 & $6.00 \mathrm{E}-03$ & 0.227 & - & - \\
\hline Toxaphene & 8.1 & 0.578571 & $2.00 \mathrm{E}-01$ & 2.892 & 1.1 & 0.636 \\
\hline Endrin & 0.0182 & 0.0013 & $3.00 \mathrm{E}-04$ & 4.333 & - & - \\
\hline Heptachlor & 14.6 & 1.042857 & 5.00E-03 & 208.571 & 4.5 & 4.692 \\
\hline Aldrin & 0.0697 & 0.004979 & $3.00 \mathrm{E}-05$ & 165.952 & 17 & 0.084 \\
\hline Heptachlor epoxide & 0.0492 & 0.003514 & $1.30 \mathrm{E}-05$ & 270.329 & 9.1 & 0.031 \\
\hline$\alpha-\mathrm{HCB}$ & 0.0127 & 0.000907 & $3.00 \mathrm{E}-04$ & 3.023 & 1.3 & 0.001 \\
\hline$\delta-\mathrm{HCB}$ & 0.0185 & 0.001321 & $8.00 \mathrm{E}-04$ & 1.651 & 1.6 & 0.002 \\
\hline$\beta-\mathrm{HCB}$ & 0.0503 & 0.003593 & 8.00E-03 & 0.449 & 1.8 & 0.006 \\
\hline$\gamma-\mathrm{HCB}$ & 0.0467 & 0.003336 & $3.00 \mathrm{E}-04$ & 11.119 & 1.1 & 0.003 \\
\hline Methoxychlor & 12.6 & 0.9 & 5.00E-03 & 180 & - & - \\
\hline Mirex & 0.0121 & 0.000864 & $1.80 E+01$ & $4.8 \mathrm{E}-05$ & - & - \\
\hline
\end{tabular}

* EDI = estimated daily intake, $\mathrm{RfD}=$ oral reference dose, $\mathrm{HQ}=$ hazard quotient, $\mathrm{SF}=$ slope factor and $\mathrm{CR}=$ Carcinogenic risk, NA $=$ Not available

Figures 


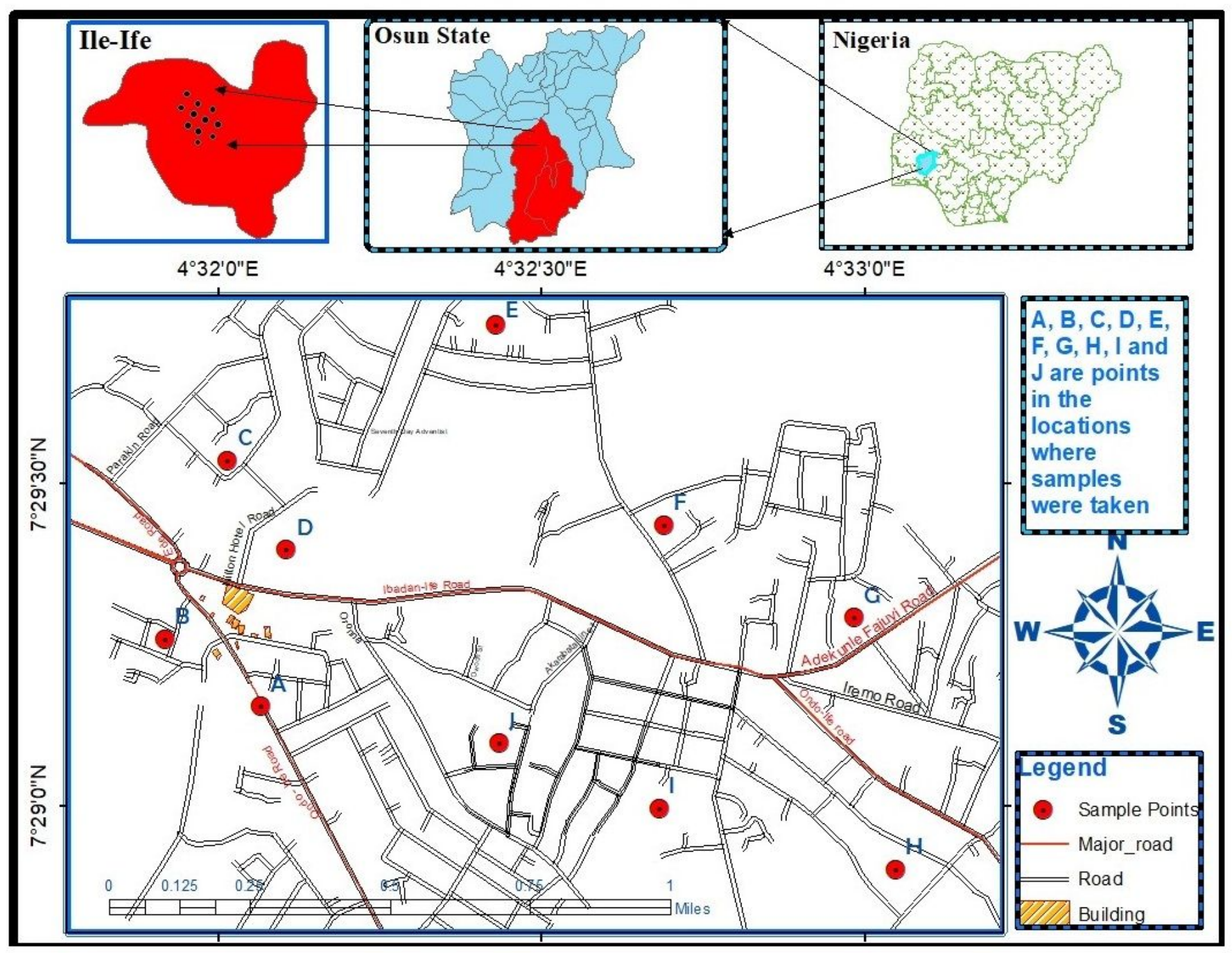

Figure 1

Map of the study area in Ile-Ife, Osun State, Nigeria, showing the sampling points. Note: The designations employed and the presentation of the material on this map do not imply the expression of any opinion whatsoever on the part of Research Square concerning the legal status of any country, territory, city or area or of its authorities, or concerning the delimitation of its frontiers or boundaries. This map has been provided by the authors. 


\section{Total OCP burden}

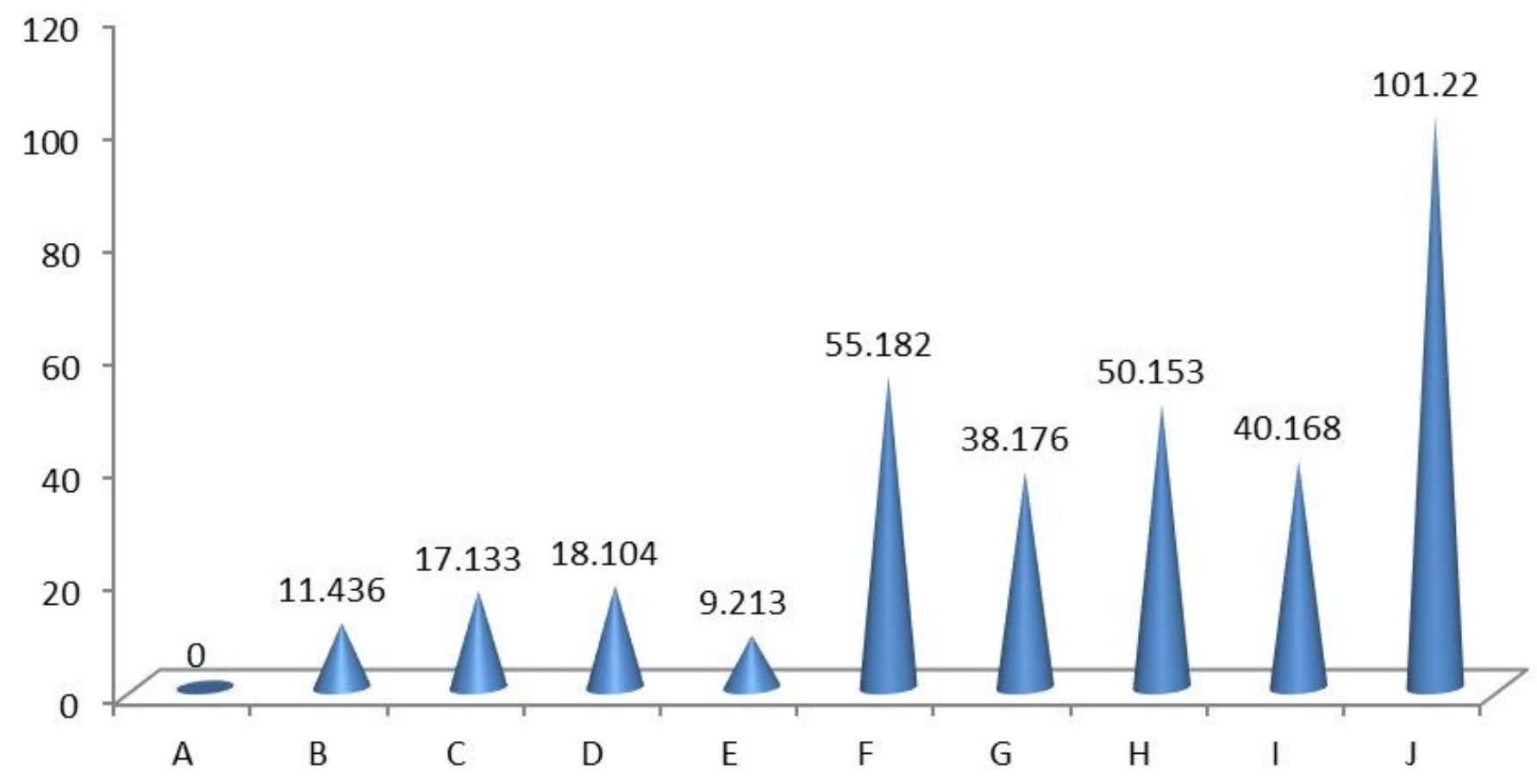

Figure 2

Total OCPs burden of the investigated areas within Ile-Ife, Osun State, Nigeria. 